\title{
Controls on the major-ion chemistry of the Dokriani glacier meltwaters, Ganga basin, Garhwal Himalaya, India
}

\author{
Syed Iobal Hasnain, Renoj. J. Thayyen \\ Himalayan Glacier Project, School of Environmental Sciences, Jawaharlal Nehru University, New Delhi 110067, India
}

\begin{abstract}
A detailed study of the major-ion chemistry of the Dokriani glacier meltwaters, feeding the Bhagirathi river, Ganga basin, Garhwal Himalaya, India, has been carried out to assess the role of active glaciers in the higher chemical-denudation rate (CDR) in this area. The CDR of the Dokriani glacier catchment is $321.6 \mathrm{t} \mathrm{km}^{-2} \mathrm{a}^{-1}$, higher than in other glacierized catchments of the world, indicating intense chemical erosion in the glacierized catchments of the Himalaya. The dominance of $\mathrm{Ca}^{2+}, \mathrm{HCO}_{3}{ }^{-}$and $\mathrm{SO}_{4}{ }^{2}$ in meltwaters throughout the 6 month (May-October) ablation period suggests that the chemical weathering is dominated by coupled reactions involving sulphide oxidation and carbonate dissolution. Good positive correlation between $\mathrm{SO}_{4}{ }^{2-}$ and suspended-sediment concentration during July and August $\left(r^{2}=0.72\right.$ and 0.67 , respectively) suggests that the southwest monsoonal rainfall enhances the weathering of supraglacial moraine and contributes significant amounts of sulphate to the high meltwater discharges. The sulphate flux, as a proportion of combined $\left(\mathrm{SO}_{4}{ }^{2}+\mathrm{HCO}_{3}\right)$ flux, also increased from $45 \%$ at $2 \mathrm{~m}^{3} \mathrm{~s}^{-1}$ to $63 \%$ at $10 \mathrm{~m}^{3} \mathrm{~s}^{-1}$.
\end{abstract}

\section{INTRODUCTION}

The Ganga river basin, Garhwal Himalaya, India, has an area of $30000 \mathrm{~km}^{2}$. It contains more than 1020 large and small glaciers (Vohra, 1993). It is estimated that $3.4 \%$ of the Ganga basin is presently covered by active glaciers (Vohra, 1981). Earlier studies of the major-ion chemistry of waters in the basin were focused on identifying the source water (Sarin and others, 1989, 1992). It was estimated that the chemical-denudation rate (CDR) of the Bhagirathi and Alaknanda river basins was 110 and $137 \mathrm{t} \mathrm{km}^{-2} \mathrm{a}^{-1}$, respectively, suggesting intense chemical weathering in the Ganga headwater catchments. The two rivers join together at Devprayag to form the river Ganga.

In this work, we studied the major-ion chemistry of Dokriani glacier meltwater, with a view to assessing the contribution of active glaciers to the higher CDRs derived for the Ganga headwater rivers. Of particular importance is the monsoon which bursts over the eastern part of the Himalaya in the first week of June and contributes a large proportion of the annual runoff in a few months (Sharma, 1993). The monsoon is deflected by mountains and moves westward, extending throughout the region by the end of July, where it persists till mid-September (Mani, 1981).

The runoff from the glacierized valleys of the Ganga river basin is first fed by snowmelt as the transient snowline recedes, and this results in discharge peaks by the end of June. However, the dense cloud cover of the southwest monsoon between July and August over the Garhwal Himalaya cuts off the radiation, and melt from the glacier ice is subdued (Collins and Hasnain, 1995). The potential of solute acquisition by meltwaters in the subglacial environment is several times higher than in other glacial environments, due to (i) the slow transit time of water within the subglacial system (Tranter and Raiswell, 1991; Tranter and others, 1993;
Brown and others, 1994, 1996; Collins, 1995), (ii) the availability of large amounts of freshly comminuted rock flour, (iii) the availability of reactive minerals, such as carbonates and sulphide in the rock flour, and (iv) the relatively rapid oxidation of sulphide in the fresh rock flour, providing additional protons for chemical weathering (Tranter and others, 1993; Brown and others, 1996).

In this paper, we present detailed chemical results from daily meltwater samples collected during May-October 1994 from the Dokriani glacier in the Ganga basin. The results are analyzed with a view to evaluating the role of monsoonal rainfall and supraglacial weathering of moraine in controlling runoff chemistry.

\section{STUDY AREA}

The Dokriani glacier is a small glacier, located in the Uttarkashi district of Uttar Pradesh. The glacier lies $25 \mathrm{~km}$ east of Bhukki. It extends from latitude $31^{\circ} 49^{\prime}$ to $35^{\circ} 20^{\prime} \mathrm{N}$ and from longitude $78^{\circ} 47^{\prime}$ to $78^{\circ} 05^{\prime} \mathrm{E}$ (Fig. 1). The total length of the glacier is $5 \mathrm{~km}$. The stream emerging at the glacial portal is Din Gad, which joins with the Bhagirathi at Bhukki. The total area of the glacier catchment is $9.58 \mathrm{~km}^{2}$, of which $5.76 \mathrm{~km}^{2}$ is glacierized. Three-quarters of the glacier ablation area is covered by thick debris. The accumulation area of the glacier is about $2.5 \mathrm{~km}^{2}$, consisting of two cirque glaciers, one originating on Draupadi ka Danda and the other on Janoli. The equilibrium line is at $\sim 4960 \mathrm{~m}$.

\section{METHODOLOGY}

Field studies were carried out for a period of 6 months from 8 May to 31 October 1994, covering the entire ablation period. Samples were collected at a gauging station estab- 


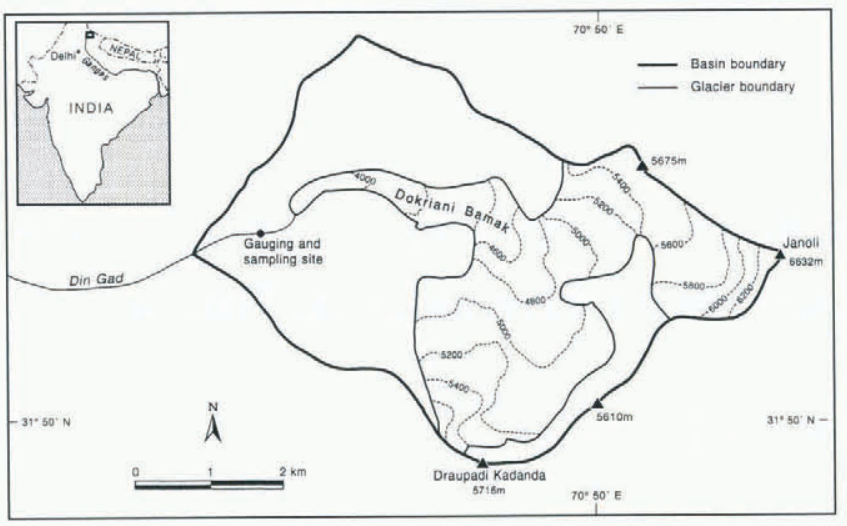

Fig. 1. Map of the Dokriani glacier catchment.

lished $600 \mathrm{~m}$ downstream from the glacier snout. Two samples were collected each day, corresponding with diurnal low flow $(0800 \mathrm{~h})$ and high flow $(1700 \mathrm{~h})$. Samples were immediately filtered through a Millipore $0.45 \mu \mathrm{m}$ membrane filter paper by using a pneumatic pump and filtration apparatus. Bicarbonate was determined in the field by using an Orion 201 auto-titrator. Fifty millilitres of the sample was titrated against $0.004 \mathrm{~N} \mathrm{HCl}$ until an end-point of $\mathrm{pH} 4.5$ was reached (APHA, 1985). Filtered samples were later brought to the laboratory at Delhi and were analyzed for the major cations $\left(\mathrm{Ca}^{2+}, \mathrm{Mg}^{2+}, \mathrm{Na}^{+}\right.$and $\left.\mathrm{K}^{+}\right)$and anions $\left(\mathrm{SO}_{4}{ }^{2-}\right.$ and $\left.\mathrm{Cl}^{-}\right)$. Analysis of cations was carried out by flame atomic absorption spectroscopy with a GBC (906) atomic absorption spectrophotometer. Calcium and magnesium were analyzed in absorption mode, and sodium and potassium were analyzed in emission mode. Sulphate analysis was carried out by a turbidimetric method, using a
GBC (911) UV/VIS spectrophotometer. The absorbance of $\mathrm{BaSO}_{4}$ suspension was measured at $420 \mathrm{~nm}$ (APHA, 1985). The minimum detection limit by this method is $1 \mathrm{mg} \mathrm{L}^{-1}$. Chloride was determined by the mercury (II) thiocyanate method (Florence and Farrar, 1971). The absorbance of chloromercurate ions was measured at $460 \mathrm{~nm}$ with a UV/ VIS spectrophotometer. Three replicates were run for cation analysis, and the instrument was recalibrated after every 15 samples. An overall precision, expressed as per cent relative standard deviation (RSD) was obtained for entire samples. Analytical precisions for $\mathrm{Ca}^{2+}, \mathrm{Mg}^{2+}, \mathrm{Na}^{+}$and $\mathrm{K}^{+}$were 1.5, 1.1, 2.0 and 1.2, respectively. Overall data reproducibility for anions was $\pm 5 \%$. Discharge was calculated by establishing a rating curve for the gauging site.

\section{RESULTS AND DISGUSSION}

The chemical composition of Dokriani glacier meltwater for low flows $(0800 \mathrm{~h})$ and high flows $(1700 \mathrm{~h})$ for selected flow regimes during the 1994 ablation period is shown in Table 1, which also shows the percentage charge balance error. The charge balance between cations and anions is $<10 \%$, confirming the reliability of the analytical results. The total cations $\left(\mathrm{TZ}^{+}\right)$and anions $\left(\mathrm{TZ}^{-}\right)$are related by the equation, $\mathrm{TZ}^{+}=0.98 \mathrm{TZ}+27.6$ with a correlation coefficient of 0.95 for 360 samples. The range of ionic concentrations during the pre-monsoon, monsoon and post-monsoon seasons of the 1994 ablation period is given in Table 2. The major anions, sulphate and bicarbonate, have ranges of $85-$ 1140 and $128-1053 \mu \mathrm{eq} \mathrm{L}{ }^{-1}$, respectively. $\mathrm{Ca}^{2+}$ was the major cation, with a concentration of 234-1941 $\mu \mathrm{eq} \mathrm{L}$, and accounts for $66-90 \%$ of the total cations. $\mathrm{K}^{+}$and $\mathrm{Mg}^{2+}$

Table 1. Major-ion composition of the Dokriani glacier meltwater at selected discharges, 8 May-31 October $1994\left(\right.$ in $\left.\mu e q L^{-1}\right)$

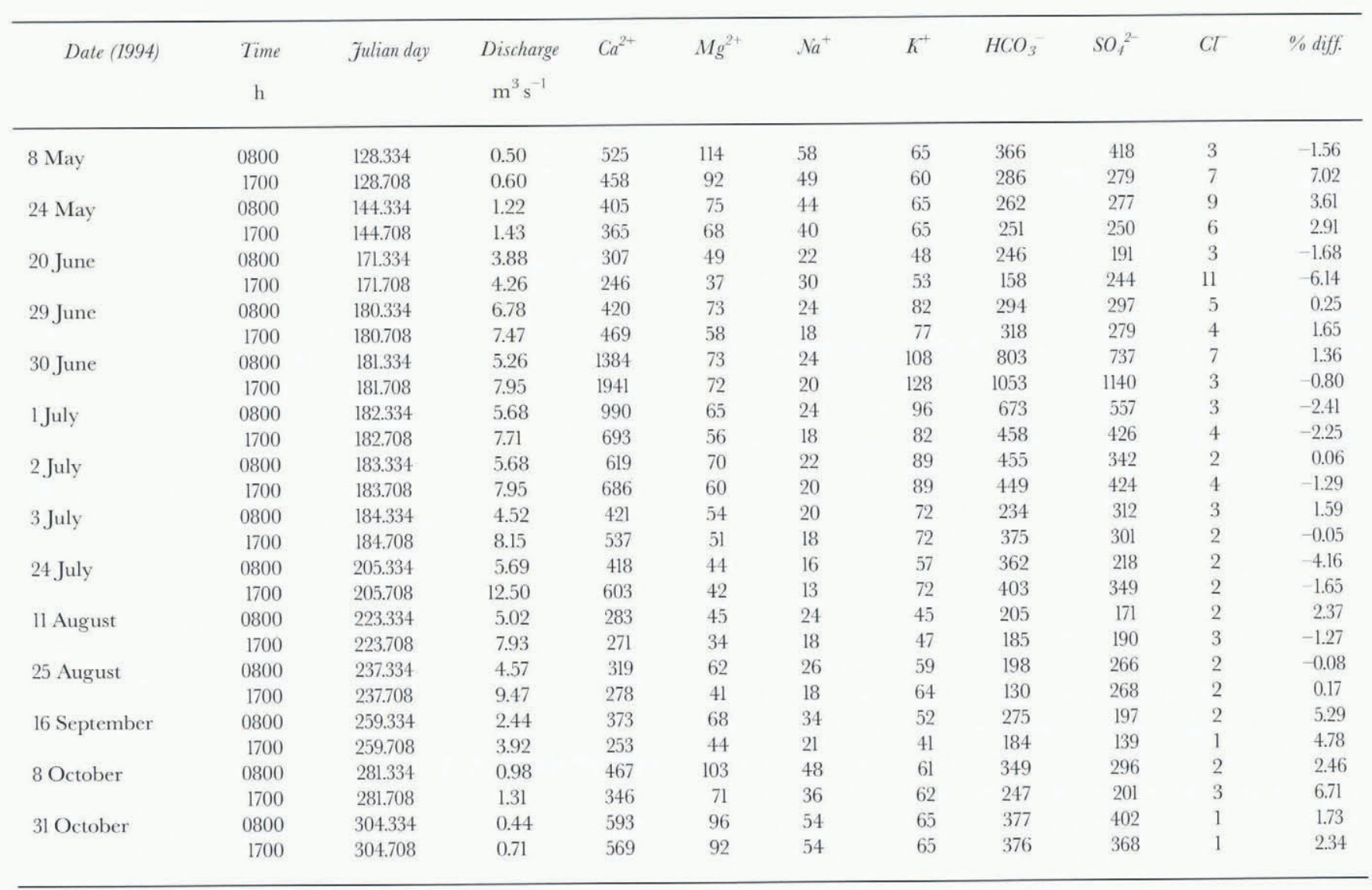


Table 2. Ionic concentration range of Dokriani glacier meltwaters in pre-monsoon, monsoon and post-monsoon seasons, MayOctober 1994

\begin{tabular}{|c|c|c|c|c|c|c|c|c|}
\hline & $\begin{array}{l}\text { Discharge } \\
\mathrm{m}^{3} \mathrm{~s}^{-1}\end{array}$ & $\begin{array}{c}\mathrm{Ca}^{2+} \\
\mu \text { eq } \mathrm{L}^{-1}\end{array}$ & $\begin{array}{l}M_{g^{2+}} \\
\mu \text { eq } L^{\prime}\end{array}$ & $\begin{array}{c}\mathrm{Na}^{+} \\
\mu \mathrm{eq} \mathrm{L}^{-1}\end{array}$ & $\begin{array}{c}K^{+} \\
\mu \text { eq } L^{\prime}\end{array}$ & $\begin{array}{l}\mathrm{HCO}_{3}^{-} \\
\mu \mathrm{eq} \mathrm{L}\end{array}$ & $\begin{array}{l}\mathrm{SO}_{t}^{2-} \\
\mu \mathrm{eq} \mathrm{L}^{-1}\end{array}$ & $\begin{array}{c}C l \\
\mu \mathrm{eq} \mathrm{L}^{-1}\end{array}$ \\
\hline $\begin{array}{l}\text { Pre-monsoon } \\
\text { Monsoon } \\
\text { Post-monsoon }\end{array}$ & $\begin{array}{l}2.81-0.41 \\
17.43-1.76 \\
3.92-0.44\end{array}$ & $\begin{array}{c}608-262 \\
1941-236 \\
593-234\end{array}$ & $\begin{array}{l}117-40 \\
80-31 \\
107-37\end{array}$ & $\begin{array}{l}65-23 \\
36-12 \\
57-20\end{array}$ & $\begin{array}{l}73-45 \\
128-41 \\
68-40\end{array}$ & $\begin{array}{c}397-1.59 \\
1053-128 \\
384-168\end{array}$ & $\begin{array}{l}418-160 \\
1140-85 \\
431-137\end{array}$ & $\begin{array}{c}24-2 \\
12-1 \\
7-1\end{array}$ \\
\hline
\end{tabular}

comprise $6-20 \%$ and $3-15 \%$ of the total cations, respectively. Table 3 shows the cationic composition of Dokriani glacier meltwater in comparison with other glaciers.

\section{SOURCES OF DISSOLVED IONS}

The chemical composition of glacial meltwaters has demonstrated high rates of chemical weathering in subglacial environments (Reynolds and Johnson, 1972; Collins, 1979; Raiswell, 1984; Sharp and others, 1995; Brown and others, 1996). The two major anions, $\mathrm{HCO}_{3}{ }^{-}$and $\mathrm{SO}_{4}{ }^{2}$, in glacial meltwaters are mainly derived from the dissolution of atmospheric carbon dioxide and carbonates, and the oxidation of sulphides (Souchez and Lemmens, 1987). Dissociation of $\mathrm{CO}_{2}$ and sulphide oxidation are the two main reactions that provide the bulk of the protons to weather carbonates, silicates and aluminosolicate in the drainage basin. The anionic content of glaciąl meltwater therefore reflects the acid sources used in the chemical weathering of bedrock minerals. The relative proportions of various ions in solution depend on their relative abundance in the bedrock and their solubility (Raiswell, 1984; Tranter and others, 1993). Sources of dissolved ions in the Dokriani glacier meltwaters can be evaluated by studying the relationship among the ions. A parametric correlation analysis for all measured ions during the 6 month observation period is given in Table $4 . \mathrm{HCO}_{3}$ and $\mathrm{SO}_{4}{ }^{2}$ are highly correlated with calcium $\left(r^{2}=0.94\right.$ and 0.92 , respectively) and with potassium $\left(r^{2}=0.71\right.$ and 0.74). The proportion of $\mathrm{HCO}_{3}$ and $\mathrm{SO}_{4}{ }^{2-}$ in the meltwaters reflects the relative dominance of the two major sources of protons during the subglacial chemical erosion. According to Brown and others (1996), the ratio of $\mathrm{HCO}_{3}{ }^{-}$to $\left(\mathrm{HCO}_{3}{ }^{-}+\mathrm{SO}_{4}{ }^{2}\right)$, referred to as the $\mathrm{C}$-ratio, has a value of 1.0 when carbonation reactions involving atmospheric $\mathrm{CO}_{2}$ dominate (as in Equations (1) and (2)), and a value of 0.5 when coupled reactions involving the weathering of carbonates by protons derived from sulphide oxidation dominate (as in Equation (3)).

$\mathrm{CaCO}_{3}(\mathrm{~s})+\mathrm{CO}_{2}(\mathrm{aq})+\mathrm{H}_{2} \mathrm{O}(\mathrm{aq})=$ (calcite)

$$
\mathrm{Ca}^{2+}(\mathrm{aq})+\mathrm{HCO}_{3}^{-}(\mathrm{aq})
$$

$\mathrm{CaAl}_{2} \mathrm{Si}_{2} \mathrm{O}_{8}(\mathrm{~s})+2 \mathrm{CO}_{2}(\mathrm{aq})+2 \mathrm{H}_{2} \mathrm{O}(\mathrm{aq})=$ (Ca-feldspar)

$$
\begin{array}{r}
\mathrm{Ca}^{2+}(\mathrm{aq})+2 \mathrm{HCO}_{3}{ }^{-}+\mathrm{H}_{2} \mathrm{Al}_{2} \mathrm{Si}_{2} \mathrm{O}_{8}(\mathrm{~s}) \\
\text { (partially weathered feldspar) }
\end{array}
$$

$$
\begin{aligned}
& 4 \mathrm{FeS}_{2}(\mathrm{~s})+16 \mathrm{CaCO}_{3}(\mathrm{~s})+15 \mathrm{O}_{2}(\mathrm{aq})+14 \mathrm{H}_{2} \mathrm{O}(\mathrm{aq})= \\
& (\text { pyrite }) \quad(\text { calcite }) \\
& 16 \mathrm{Ca}^{2+}(\mathrm{aq})+16 \mathrm{HCO}_{3}{ }^{-}(\mathrm{aq})+8 \mathrm{SO}_{4}{ }^{2-}(\mathrm{aq})+4 \mathrm{Fe}(\mathrm{OH})_{3}(\mathrm{~s}) .
\end{aligned}
$$

The C-ratio of the Dokriani glacier meltwater during May and June is 0.5 (Fig. 2), suggesting the dominance of carbonate dissolution and the oxidation of sulphides (Brown and others, 1994). From late June to early July (Julian days

\begin{tabular}{|c|c|c|c|c|c|c|c|}
\hline \multirow[t]{2}{*}{ Glacier } & \multirow[t]{2}{*}{ Date } & \multirow{2}{*}{$\begin{array}{l}\text { Number } \\
\text { of samples }\end{array}$} & \multicolumn{4}{|c|}{ Range of $\%$ as $\%\left(\mathrm{Ca}^{2+}+\mathrm{Mg}^{2}+\mathrm{Na}^{+}+\mathrm{K}^{+}\right)$} & \multirow[t]{2}{*}{ Source } \\
\hline & & & $\mathrm{Ca}^{2+}$ & $\mathrm{Mg}^{2+}$ & $\mathrm{Na}^{+}$ & $K^{+}$ & \\
\hline Dokriani glacier & $\begin{array}{c}\text { August-September } 1992 \\
\text { October-November } 1993 \\
\text { May-October } 1994\end{array}$ & $\begin{array}{l}180 \\
88 \\
360\end{array}$ & $\begin{array}{l}45-70 \\
39-75 \\
66-90\end{array}$ & $\begin{array}{ll}3 & 28 \\
9 & 21 \\
3 & -15\end{array}$ & $\begin{array}{l}6-18 \\
6-18 \\
9-15\end{array}$ & $\begin{array}{ll}8 & -18 \\
8 & -21 \\
7 & -23\end{array}$ & $\begin{array}{l}\text { This study } \\
\text { This study } \\
\text { This study }\end{array}$ \\
\hline Gornergletscher & $\begin{array}{c}\text { July-August } 1974 \\
\text { July-September } 1975 \\
\text { July-August } 1976\end{array}$ & $\begin{array}{l}69 \\
59 \\
41\end{array}$ & $\begin{array}{cc}45 & 90.9 \\
57 & 71.3 \\
52.7-76.1\end{array}$ & $\begin{array}{c}5.2-23.3 \\
14-18 \\
13.5-17.6\end{array}$ & $\begin{array}{l}1.3-17.4 \\
1.9-8.8 \\
3.2-8.1\end{array}$ & $\begin{array}{l}1.8-22.0 \\
9.6-26.5 \\
3.9-25.0\end{array}$ & $\begin{array}{l}\text { Collins (1979) } \\
\text { Collins (1979) } \\
\text { Collins (1979) }\end{array}$ \\
\hline Lewis Glacier & June-August 1974 & 14 & $38.1-39.7$ & $7.5-11.0$ & $44.6-47.0$ & $4.7-12.4$ & Church (1974) \\
\hline
\end{tabular}
174-187), high discharges were derived largely from iceand snowmelt, which rapidly passed through the hydro-

Table 4. Correlation matrix for ions, May-October 1994

\begin{tabular}{lcccccc}
\hline & $\mathrm{Ca}^{2+}$ & $\mathrm{Mg}^{2+}$ & $\mathrm{Na}^{+}$ & $\mathrm{K}^{+}$ & $\mathrm{HCO}^{3-}$ & $\mathrm{SO}_{1}^{2}$ \\
\hline $\mathrm{Ca}^{2+}$ & - & & & & & \\
$\mathrm{Mg}^{2+}$ & 0.50 & & & & & \\
$\mathrm{Na}^{+}$ & 0.35 & 0.93 & - & & & \\
$\mathrm{K}^{+}$ & 0.76 & 0.30 & 0.10 & - & & \\
$\mathrm{HCO}_{3}$ & 0.94 & 0.53 & 0.38 & 0.71 & - & \\
$\mathrm{SO}_{4}{ }^{2+}$ & 0.92 & 0.47 & 0.35 & 0.74 & 0.80 & - \\
$\mathrm{Cl}^{2}$ & 0.15 & 0.28 & 0.39 & 0.14 & 0.13 & 0.18 \\
\hline
\end{tabular}

Table 3. Summary of cationic composition of Dokriani glacier meltwater in comparison with olher glaciers 

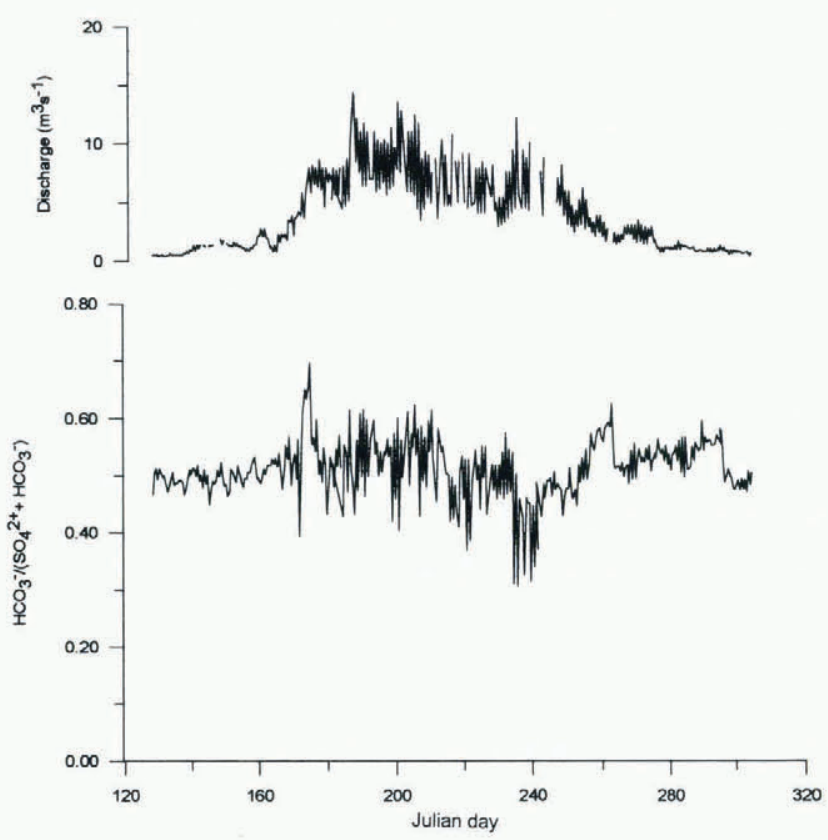

Fig. 2. Ratio of $\mathrm{HCO}_{3}{ }^{-}$to $\left(\mathrm{HCO}_{3}{ }^{-}+\mathrm{SO}_{4}{ }^{2}\right)$ in bulk meltwaters draining the Dokriani glacier, May-October 1994.

logical system. The enhanced C-ratio (0.55 and 0.7) during this period indicates that protons are additionally derived from the dissolution and dissociation of atmospheric $\mathrm{CO}_{2}$ (Brown and others, 1996). During July and August (Julian days 195-243), cloud cover over the Himalaya, linked to the onset of the southwest monsoon, cuts off radiation and causes snowfall in the accumulation zone and rainfall in the ablation region (Collins and Hasnain, 1995). Meltwater discharges during this cloudy, monsoonal period were likely to be sustained by drainage of a subglacial reservoir built over the previous months. Hence, runoff contains a very high proportion of stored subglacial water. The C-ratio during this period varies between 0.31 and 0.63 , suggesting the dominance of carbonate dissolution and sulphide oxidation in controlling the meltwater composition. The cloudburst on 24 August (Julian day 236) resulted in high discharge $\left(17.45 \mathrm{~m}^{3} \mathrm{~s}^{-1}\right)$ and the lowest C-ratio (0.31), as shown in Figure 2, suggesting that rainfall running through supraglacial moraine may also have a strong control on the chemical characteristics of meltwater.

Figure 3 shows the relationship of $\mathrm{SO}_{4}{ }^{2-}$ and $\mathrm{HCO}_{3}{ }^{-}$to total cations for the rising limb, the crest segment and the falling limb of all hydrographs from May through October. Both sulphate and bicarbonate show good correlation with $\mathrm{TZ}^{+}$on the rising limb, with sulphate showing better correlation, whereas bicarbonate was better correlated to $\mathrm{TZ}^{+}$on the falling limb. The crest segment is characterised by comparatively low correlation of $\mathrm{TZ}^{+}$with bicarbonate and sulphate individually, but the relationship improves to $r^{2}=0.82$ when bicarbonate and sulphate are combined. These data show that pyrite oxidation and carbonate dissolution are dominant solute suppliers to waters on the ascending limb of the hydrograph, and that carbonation reactions became more important on the falling limb of the hydrograph.

\section{ROLE OF MONSOONAL RAINFALL AND WEATH- ERING OF SUPRAGLACIAL MORAINE}

A total of $1269 \mathrm{~mm}$ of rainfall fell on the Dokriani glacier
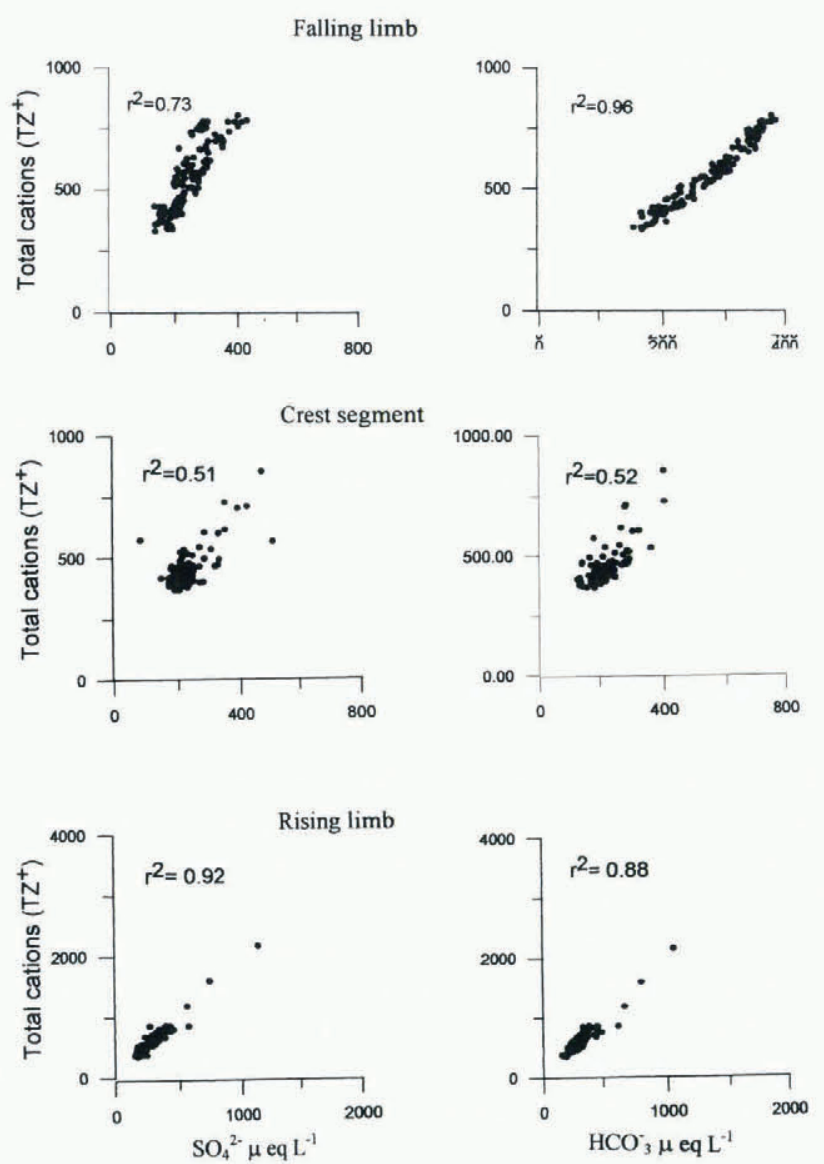

Fig. 3. Relationship of $\mathrm{SO}_{4}{ }^{2-}$ and $\mathrm{HCO}_{3}^{-}$to total cations for rising limb, crest segment and falling limb, May-October 1994.

during the May-October 1994 observation period, mostly during the months of July and August. This rainfall pushed large quantities of debris into the glacier sole through crevasses (Hasnain and Chauhan, 1993). During June, $\mathrm{HCO}_{3}$ and $\mathrm{SO}_{4}{ }^{2-}$ show a good positive correlation with suspendedsediment concentrations $\left(r^{2}=0.84\right.$ and 0.89 , respectively), as shown in Figure 4. This probably indicates the dominance of water from a solute-rich source, water either discharged through sediments at the glacier bed or that has been kept in storage for a long period, as a major transporter of suspended sediment. Successive diurnal melting of snow and ice rapidly leaches most of the sulphate from the snow and ice (Davies and others, 1987). Later in the ablation season, the leached snow and ice gives rise to sulphate-depleted supraglacial meltwater (Tranter and Raiswell, 1991). The release of sulphate by the oxidation of sulphides in suspended sediment is a slow process and therefore is only likely to contribute significant sulphate concentrations to waters which have spent long periods at the glacier bed in contact with sediments (Brown and others, 1994). However, contrary to these observations, Dokriani glacier meltwaters show higher sulphate concentrations during July and August and show good positive correlation between $\mathrm{SO}_{4}{ }^{2-}$ and suspended-sediment concentration $\left(r^{2}=0.72\right.$ and 0.67 , respectively $)$, as shown in Figure 4. One possible explanation is as follows: Continuous low-intensity rainfall may have initiated pyrite oxidation within the supraglacial moraines. Thereafter, occasional high-intensity showers may leach the sulphate from the debris and cause its domination during the seasonal high-flow period of July and August, when suspended-sediment concentra- 

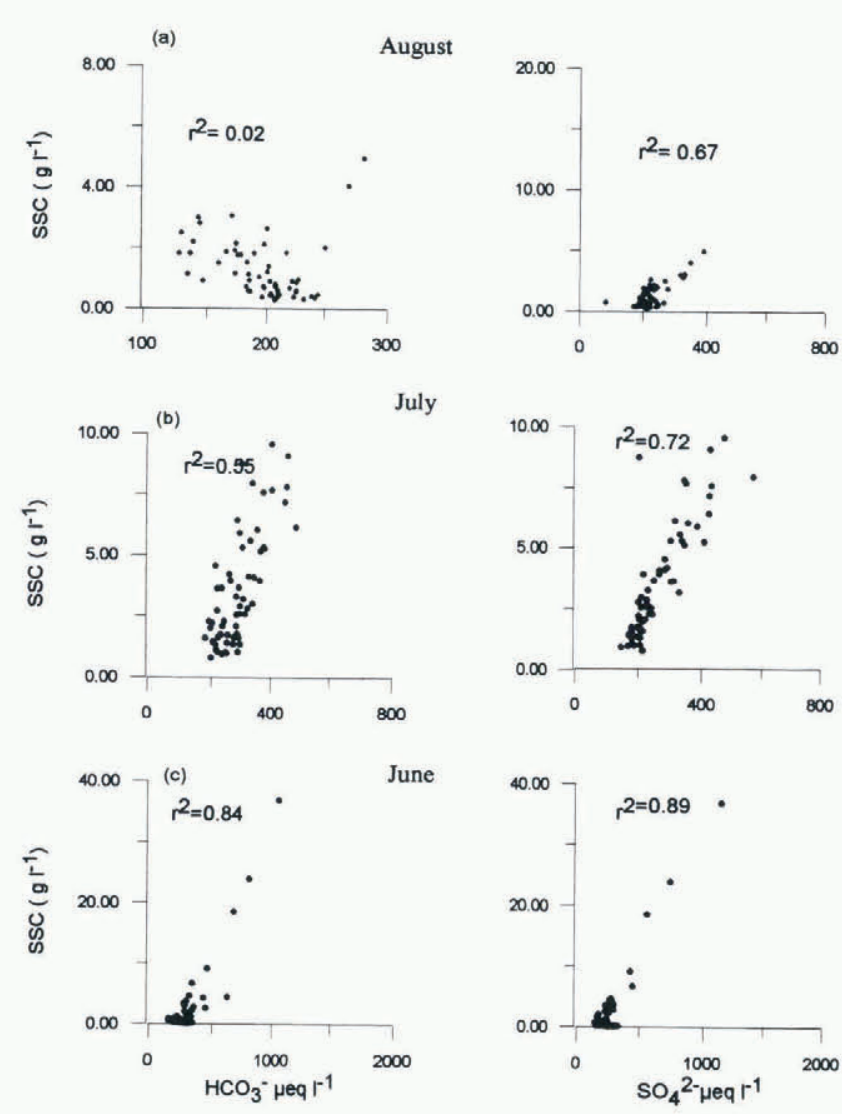

Fig. 4. Relationship between $\mathrm{SO}_{4}{ }^{2-}$ and $\mathrm{HCO}_{3}{ }^{-}$with suspended-sediment concentration (SSC) for June-August 1994.

tions are high. The percentage contribution of suspended sediments from the supraglacial sources in the bulk flow is not known. The post-monsoon dry period of September exhibits a weak correlation between $\mathrm{SO}_{4}{ }^{2-}$ and suspended-sediment concentration $\left(r^{2}=0.09\right)$, and thus substantiates the observation of Tranter and others (1993) that reactive sulphides will be largely absent from rock flour transported from the subglacial system.

\section{SOLUTE FLUXES AND CHEMICAL-DENUDATION RATES}

Solute fluxes in glacial meltwaters usually increase with discharge. The largest solute fluxes are transported by the most dilute meltwater as solute concentration is usually inversely related to discharge (Sharp and others, 1995). Figure 5 shows the relationship between the fluxes of $\mathrm{SO}_{4}{ }^{2}$ and $\mathrm{HCO}_{3}$ with the glacial discharge. The flux of $\mathrm{SO}_{4}{ }^{2-}$ as a proportion of the flux of $\mathrm{SO}_{4}{ }^{2-}+\mathrm{HCO}_{3}{ }^{-}$increases from $40-45 \%$ at $2 \mathrm{~m}^{3} \mathrm{~s}^{-1}$ to $40-63 \%$ at $10 \mathrm{~m}^{3} \mathrm{~s}^{-1}$. This reinforces our contention that the weathering of supraglacial moraines initiated by monsoonal rainfall enhances the sulphate concentration at high discharges. This is contrary to the results obtained by Sharp and others (1995) in the catchment of Haut Glacier d'Arolla in Switzerland.

The cationic deundation rates from some of the important glaciers in the European Alps and North America are given in Table 5 . The cationic denudation rate of Dokriani glacier is $4160 \mathrm{meq} \mathrm{m}^{-2} \mathrm{a}^{-1}$, about four times higher than the highest recorded at Gornergletscher, Swiss Alps (Metcalf, 1986). The CDR of the Dokriani glacier was $321 \mathrm{t} \mathrm{km}^{-2} \mathrm{a}^{-1}$. Monthly values of chemical denudation during the 1994
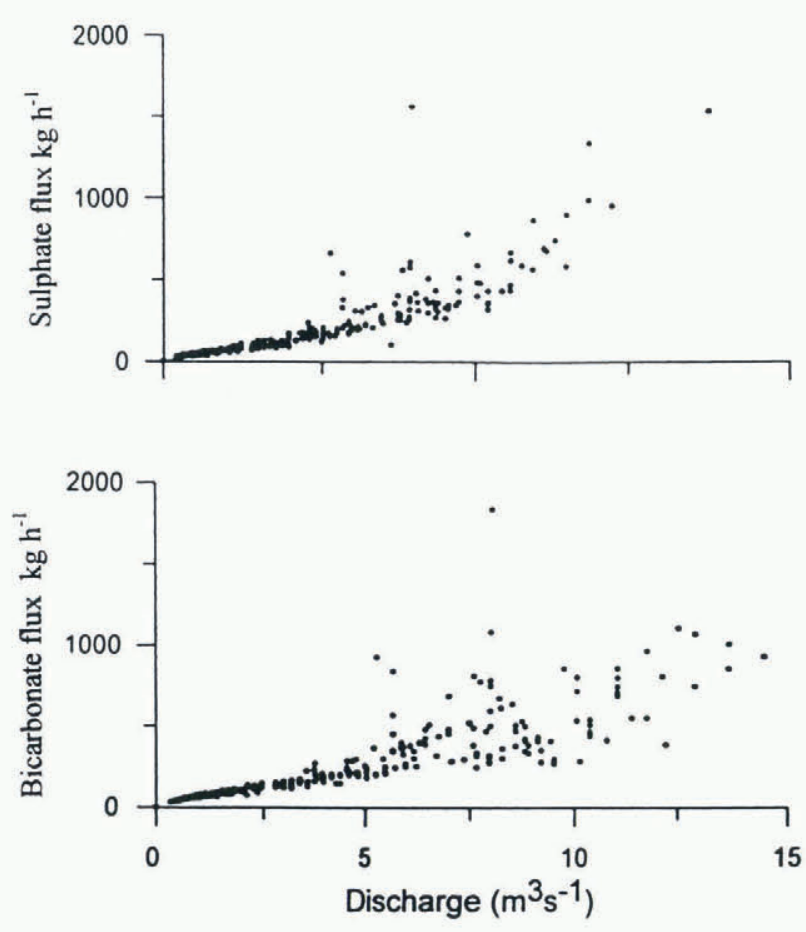

Fig. 5. Relationship between the fluxes of $\mathrm{SO}_{4}{ }^{2}$ and $\mathrm{HCO}_{3}{ }^{\text {. }}$ with meltwater discharge during May-October 1994.

observation period are given in Table 6. The high CDR substantiates our observation that the high relief, southwest monsoonal rainfall and supraglacial moraines are very significant in controlling the chemistry of Garhwal Himalaya glacial meltwaters.

\section{CONGLUSIONS}

A detailed hydrochemical study of Dokriani glacier meltwater has been carried out with a view to evaluating the controls on the major-ion chemistry of the glacierized Himalayan basin. The important conclusions are:

1. The dominance of $\mathrm{Ca}^{2+}, \mathrm{HCO}^{3-}$ and $\mathrm{SO}_{4}{ }^{2-}$ in meltwaters throughout the ablation period suggests that the meltwater chemistry is dominated by coupled reactions involving sulphide oxidation and carbonate dissolution.

2. High sulphate concentrations and the good relationship between $\mathrm{SO}_{4}{ }^{2-}$ and suspended-sediment concentrations

Table 5. Cationic denudation rates of the Dokriani glacier in comparison with other glaciers

\begin{tabular}{cc}
\hline $\begin{array}{c}\text { Denudation } \\
\text { rate }\end{array}$ & Source \\
meq m$^{-2} \mathrm{a}^{-1}$ & \\
\hline
\end{tabular}

European glaciers (Swiss Alps)

Haut Glacier d'Arolla

640-685 Sharp and others (1995

Glacier de Tsijiore Nouve

Gornergletscher

Gornergletscher

Collins (1983)

North American glaciers

South Cascade Glacier (WA) $930 \quad$ Reynolds and Johnson (1972)

Berendon Glacier (B.C.) $947 \quad$ Eyles and others (1982)

Southern Himalaya

Dokriani glacier

4160

This study 
Table 6. Monthly solute flux and chemical-denudation rates of Dokriani glacier catchment, 1994

\begin{tabular}{lccc}
\hline Month & Solute flux & Solute flux & CDR \\
& $\mathrm{t}$ & $\%$ & $\mathrm{t} \mathrm{km}^{-2}$ \\
\hline May & 86.0 & 3.0 & 9.0 \\
June & 431.0 & 18.0 & 45.0 \\
July & 970.0 & 40.0 & 101.0 \\
August & 563.0 & 23.0 & 59.0 \\
September & 279.0 & 11.0 & 29.0 \\
October & 124.0 & 5.0 & 13.0 \\
\hline
\end{tabular}

during July and August suggests that the monsoonal rainfall enhances the supraglacial moraine weathering, providing high $\mathrm{SO}_{4}{ }^{2}$ content in the meltwater during periods of high discharge. This is substantiated by observed higher sulphate fluxes during high discharges.

3. The CDR of the Dokriani glacier catchment is $321.6 \mathrm{t} \mathrm{km}^{-2} \mathrm{a}^{-1}$, suggesting very high rates of chemical weathering in the southern Himalayan glaciers.

\section{ACKNOWLEDGEMENTS}

We thank the Department of Science and Technology, Government of India, for providing financial assistance for the Dokriani glacier studies.

\section{REFERENCES}

American Public Health Association (APHA). 1985. Standard melhods for the examination of water and wastewater. Sixteenth edition. New York, American Public Health Association.

Brown, G. H., M. J. Sharp, M. Tranter, A. M. Gurnell and P. W. Nienow. 1994. Impact of post-mixing chemical reactions on the major ion chemistry of bulk meltwaters draining the Haut Glacier d'A rolla, Valais, Switzerland. Hydrol. Processes, 8 5), 465-480.

Brown, G. H., M. Sharp and M. Tranter. 1996. Subglacial chemical erosion: seasonal variations in solute provenance, Haut Glacier d'Arolla, Valais, Switzerland. Ann. Glaciol., 22, 25-31.

Church, M. 1974. On the quality of some waters on Baffin Island, Northwest Territories. Can. 7. Earth Sci., 11 (12), 1676-1688.

Collins, D. N. 1979. Hydrochemistry of meltwaters draining from an Alpine glacier. Arct. Alp. Res., 11 (3), 307-324.

Collins, D. N. 1983. Solute yield from a glacierised high mountain basin. International Association of Hydrological Sciences Publication 141 (Symposium at Hamburg 1983 - Dissolved Loads of Rivers and Surface Water Quantity/ Quality Relationships), 41-49.

Collins, D. N. 1995. Dissolution kinetics, transit times through subglacial hydrological pathways and diurnal variations of solute content of meltwaters draining from an Alpine glacier. Hydrol. Processes, 9, 897-910.

Collins, D. N. and S. I. Hasnain. 1995. Runoff and sediment transport from glacierized basins at the Himalayan scale. International Association of Hydrological Sciences Publication 226 (Symposium at Boulder 1995 - Effects of Scale on Interpretation and Management of Sediment and Water Quality), 17 - 25.

Davies, T. D. and 6 others. 1987. The removal of soluble ions from melting snow packs. In Jones, H. G. and W. J. Orville-Thomas, eds. Seasonal snowcovers: physics, chemistry, hydrology. Dordrecht, etc., D. Reidel Publishing Co., 337-392. (NATO ASI Series C: Mathematical and Physical Sciences 211 .

Eyles, N., D. R. Sasseville, R. M. Slatt and R.J. Rogerson. 1982. Geochemical denudation rates and solute transport mechanisms in a maritime temperate glacier basin. Can. J. Earth Sci., 19(8), 1570-1581.

Florence, T. M. and Y.J. Farrar. 1971. Spectrophotometric determination of chloride at the parts per billion level by mercury (II) thiocynate method. Anal. Chim. Acta, 54,373-377.

Hasnain, S. I. and D. S. Chauhan. 1993. Sediment transfer in the glaciofluvial environment - a Himalayan perspective. Environ. Geol., 22, 205-211.

Mani, A. 1981. The climate of the Himalaya. In Lal, J. S. and A. D. Moddie, eds. The Himalaya: the aspects of change. Oxford, Oxford University Press, 3-15.

Metcalf, R. C. 1986. The cationic denudation rate of an Alpine glacial catchment. Z. Gletscherkd. Glazialgeol., 22 (1), 19-32.

Raiswell, R. 1984. Chemical models of solute acquisition in glacial melt waters. J. Glaciol., 30 (104), 49-57.

Reynolds, R. C., Jr and N. M. Johnson. 1972. Chemical weathering in the temperate glacial environment of the Northern Cascade Mountains. Geochim. Cosmochim. Acta, 36 (5), 537-554.

Sarin, M. M., S. Krishnaswamy, K. Dilli, B. L. K. Somayajulu and W. S. Moore. 1989. Major ion chemistry of the Ganga-Brahmaputra river system: weathering processes and fluxes to the Bay of Bengal. Geochim. Cosmochim. Acta, 53, 997-1009.

Sarin, M. M., S. Krishnaswamy, J. R. Trivedi and K. K. Sharma. 1992. Major ion chemistry of the Ganga source waters: weathering in the high altitude Himalaya. Proc. Indian Acad. Sci., Sect. A, 101 (1) $89-98$.

Sharma, K. P. 1993. Role of meltwater in major river systems of Nepal. International Association of Hydrological Sciences Publication 218 (Symposium at Kathmandu 1992 - Snow and Glacier Hydrology), 113-122.

Sharp, M., G. H. Brown, M. Tranter, I. C. Willis and B. Hubbard. 1995. Comments on the use of chemically based mixing models in glacier hydrology. 7. Glaciol., 41 (138), $241-246$.

Souchez, R. A. and M. M. Lemmens. 1987. Solutes. In Gurnell, A. M. and M.J. Clark, eds. Glacio-fluvial sediment transfer: an alpine perspective. Chichester, etc., John Wiley and Sons, 285-303.

Tranter, M. and R. Raiswell. 1991. The composition of the englacial and subglacial component in bulk meltwaters draining the Gornergletscher, Switzerland. f. Glaciol., 37 (125), $59-66$.

Tranter, M., G. Brown, R. Raiswell, M. Sharp and A. Gurnell. 1993. A conceptual model of solute acquisition by Alpine glacial meltwaters. 7 . Glaciol., 39 (133), 573-581.

Vohra, C. P. 1981. Himalayan glaciers. In Lal, J. S. and A. D. Moddie, eds. The Himalaya: the aspects of change. Oxford, Oxford University Press, $138-151$.

Vohra, C. P. 1993. Himalayan glaciers. In Iyer, R., ed. Harnessing the eastern Himalayan rivers. New Delhi, Konark Publishers Pvt. Ltd., 59-69. 